\title{
Fly ash as zeolites for reducing nitrogen losses by volatilization
}

\section{Uso de cinzas como zeólitas na redução de perdas de nitrogênio por volatilização}

\author{
Carlos Antonio Costa do Nascimento ${ }^{1 *}$; Letícia de Abreu Faria ${ }^{2}$; \\ Godofredo Cesar Vitti ${ }^{3}$; Erik Lew Kenzo Ono ${ }^{4}$; Eduardo Zavaschi ${ }^{1}$
}

\begin{abstract}
The structural and chemical characteristics of fly ash from coal-fired mineral and fly ash zeolitized are similar to those of zeolites. Urea was added with these materials in the proportions of urea: fly ashes of 100:10, 100:20, 100:50, 100:100, with a control containing just urea. These treatments were applied in soil surface and the experimental design was a randomized block with clay and sandy soil. Nitrogen losses by ammonia volatilization and the chemical characteristics of soil fertility were evaluated. In sandy soil there was reduction of ammonia volatilization for the proportions of 100:10 and 100:20, while fly ash zeolitized and fly ash had no difference.
\end{abstract}

Key words: Alumino-silicate, ammonia, cation exchange capacity, residue, urea

\section{Resumo}

As cinzas provenientes da queima de carvão mineral, seja in natura ou zeolitizada, possuem estrutura e características químicas semelhantes às zeólitas. Verificou-se a adição destes materiais à ureia nas proporções ureia:cinzas 100:10, 100:20, 100:50, 100:100 e um controle (somente ureia), em delineamento com blocos casualizados em solo arenoso e argiloso sem incorporação, avaliando as perdas de nitrogênio por volatilização de amônia e os parâmetros químicos de fertilidade do solo. As proporções 100:10 e 100:20 promoveram redução significativa de perdas por volatilização da amônia, porém somente no solo de textura arenosa. Não há diferença entre a cinza zeolitilizada e a cinza in natura visando à redução das perdas de $\mathrm{N}$ por volatilização de $\mathrm{NH}_{3}$ da ureia.

Palavras-chave: Aluminossilicatados, amônia, capacidade de troca catiônica, resíduo, ureia

\footnotetext{
${ }^{1}$ Doutorando(s) do Programa de pós-graduação de Solos e Nutrição de Plantas na Escola Superior de Agricultura Luiz de Queiroz, Universidade de São Paulo, ESALQ, Piracicaba, SP. Bolsista CAPES. E-mail: cacnagro@yahoo.com.br; eduzavaschi@yahoo. com.br

${ }^{2}$ Doutoranda Programa de pós-graduação de Solos e Nutrição de Plantas, ESAPQ, São Paulo, SP. Bolsita FAPESP. E-mail: evazoot@yahoo.com.br

${ }^{3}$ Prof. Titular, Dept ${ }^{\circ}$ de Ciências do Solo, ESALQ, São Paulo, SP. E-mail: gcvitti@usp.br

${ }^{4}$ Discente em Engenharia Agronômica, ESALQ, São Paulo, SP. E-mail: erik.ono@usp.br

* Author for corespondence
} 
Natural zeolites have been applied in agriculture and environmental protection, metal remediation in water and soils, animal nutrition and aquiculture (BERNARDI et al., 2008). Agriculture is identified as a promissory market for zeolite utilization due to competitive prices and the large quantities requested. Thermoelectric mills produce huge ash quantities by burning mineral-coal. Ashes may work as zeolite applied to urea due to their composition of silica $\left(\mathrm{SiO}_{2}\right)$ and alumina $\left(\mathrm{Al}_{2} \mathrm{O}_{3}\right)$.

Studies have been developed to determine the use and value aggregation for residues generated in consequence of the intensive production of industrial residues and pressure of social and environmental institutions along with lack of raw materials. Agriculture is becoming the main destination for industrial residues in consequence to the possibilities of economic gains as alternative sources of nutrients with lower costs to farmers as well as to factories with valorizing sub-products.

Residues application in agriculture must promote benefits such as nutrient sources, increasing fertilizer efficiency in plants, stimulating soil microorganisms, etc.; however, they must not contain toxic elements.

Urea is the most frequently used nitrogen source in Brazil; however, its reaction in soil shows a large potential of loss by ammonia volatilization (CANTARELLA et al., 2003; VITTI et al., 2007). Materials to slow or control release may improve the efficient use of urea. Extended or slow initial availability of slow release fertilizers occurs via several mechanisms. These include the solubility of the material by semi-permeable coatings, occlusion, protein materials, or other chemical forms, by slow hydrolysis of water-soluble low molecular weight compounds or by other unknown means (TRENKEL, 2010).

Zeolite added to urea has been evaluated as a method to reduce ammonia volatilization through decrease of $\mathrm{N}$ content in soil solution by cationic exchange (BERNARDI et al., 2008).
Slow- and controlled-fertilizers have been developed through materials added to urea to reduce nitrogen losses by ammonia volatilization. These materials act by inhibiting the urease enzyme and the time of urea solubilization in soil (SOARES, 2008). Zeolite belongs to these materials that can be added to urea to reduce ammonia volatilization.

According to Soares (2008), zeolite may increase fertilizer efficiency through its high capacity of cation exchange, water retention and adsorption ability. The slow release of nitrogen is controlled in two ways: physical coat and exchange of ammonium inside of the zeolite (ELLIOT; ZHANG, 2005). Zeolite consists of tetrahedrons of $\left[\mathrm{SiO}_{4}\right]^{4-}$ and $\left[\mathrm{AlO}_{4}\right]^{4-}$ whose organization determines its classification. The structure of zeolite consists of channels and cavities that work as a sieve with selective cationic exchange properties (OSTE, LEXMOND, VAN RIEMSDIJK, 2002).

The mechanism of action of zeolite involves the decrease of $\mathrm{N}$ content in soil solution by cationic exchange, mainly in soils with lower exchange cationic capacity, and ammonium retention resulting in high rates of volatilization (OLIVEIRA, 2001). In this way it retains large quantities of ammonium and also, interferes in the nitrification process (BARTZ; JONES, 1983; FERGUSON; PEPPER, 1987).

This study was carried out to determine if urea coated with ashes in natura and zeolitilized are capable of reducing nitrogen loss by volatilization compared to urea, as well as if they can modify chemical and fertility parameters of soil.

The study was carried out in a greenhouse under temperature- and humidity-controlled conditions at the Department of Soil Sciences of Escola Superior de Agricultura Luiz de Queiroz - University of São Paulo in Piracicaba - SP.

The ash (Table 1 and 2) was stirred along with urea until the granules showed total and homogeneous coverage of ash. The urea quantity applied in the soil surface was equivalent to $100 \mathrm{~kg} \mathrm{ha}^{-1}$ of $\mathrm{N}$ as urea. Fertilizer was applied in the soil surface of 
pots as well as in the inter-row management of crops $\mathrm{N}$ in each experimental unit $(17.2 \mathrm{~cm}$ diameter of $(0.8 \mathrm{~m})$, i.e. $3.06 \mathrm{~g}$ of urea corresponding to $1.38 \mathrm{~g}$ of each pot).

Table 1. Characteristics of ashes.

\begin{tabular}{|c|c|c|c|c|c|c|c|c|c|c|c|}
\hline \multicolumn{12}{|c|}{ Ashes analyzed as fertilizers } \\
\hline \multirow{2}{*}{ Material } & $\mathrm{K}_{2} \mathrm{O}$ & $\mathbf{C a}$ & Mg & $\mathbf{S}$ & $\mathbf{F e}$ & Mn & $\mathbf{Z n}$ & $\mathbf{N}$ & B & Cl & $\mathbf{C u}$ \\
\hline & \multicolumn{10}{|c|}{$\%$} & $\mathrm{mg} \mathrm{kg}^{-1}$ \\
\hline Ash in natura & 0.05 & 2.53 & 0.24 & 1.17 & 3.56 & 0.05 & 0.08 & 0.01 & 0.08 & 0.06 & 15 \\
\hline Zeolitized ash & 0.18 & 1.22 & 0.58 & 0.36 & 3.30 & 0.03 & 0.12 & 3.10 & 0.03 & 0.13 & 23 \\
\hline \multicolumn{12}{|c|}{ Ashes analysed as limestones } \\
\hline Material & $\mathrm{CaO}$ & $\mathrm{MgO}$ & \multicolumn{3}{|c|}{$\begin{array}{c}\text { Silica and insolubles } \\
\%\end{array}$} & $\mathbf{N P}$ & RPTN & CEC & W-HC & & \\
\hline $\begin{array}{c}\text { Ash } \\
\text { in natura }\end{array}$ & 4.37 & 0.0 & \multicolumn{3}{|c|}{72.94} & 2.50 & 2.50 & 40 & 94 & & \\
\hline Zeolitized ash & 3.76 & 1.86 & \multicolumn{3}{|c|}{41.0} & 18.0 & 18.0 & 80 & 96 & & \\
\hline
\end{tabular}

Source: Elaboration of the authors.

Table 2. Analysis of physical and chemical contents by IAC.

\begin{tabular}{|c|c|c|c|}
\hline Material & Unit $^{(1)}$ & Ash in natura & Zeolitilized ash \\
\hline Humidity $60-65^{\circ} \mathrm{C}$ & $\%(\mathrm{~m} / \mathrm{m})$ & 5.8 & 6.7 \\
\hline Organic carbon & $\mathrm{g} \mathrm{kg}^{-1}$ & 146 & 59.7 \\
\hline Nitrogen (Kjeldahl) & $\mathrm{g} \mathrm{kg}^{-1}$ & 2.2 & 1.3 \\
\hline $\mathrm{C} / \mathrm{N}$ relation & & 66.8 & 45.8 \\
\hline As & & 450 & 490 \\
\hline $\mathrm{B}$ & & 63.3 & 34.6 \\
\hline $\mathrm{Cd}$ & & 1.4 & 7.9 \\
\hline $\mathrm{Ca}$ & & 29.5 & 9.7 \\
\hline $\mathrm{Pb}$ & & 44.5 & 265 \\
\hline $\mathrm{Cr}$ & & 13.2 & 38.2 \\
\hline $\mathrm{Cu}$ & & 11.1 & 19.8 \\
\hline $\mathrm{Fe}$ & $\mathrm{mg} \mathrm{kg}^{-1}$ & 9582 & 16847 \\
\hline $\mathrm{Mn}$ & & 558 & 233 \\
\hline $\mathrm{Hg}$ & & $<1.0^{(2)}$ & 2.8 \\
\hline $\mathrm{Ni}$ & & 6.2 & 22.0 \\
\hline $\mathrm{Se}$ & & 6.3 & 11203 \\
\hline $\mathrm{K}$ & & 1386 & 2.1 \\
\hline $\mathrm{Zn}$ & & 207 & 1160 \\
\hline Soluble Si & & 1093 & 74.6 \\
\hline $\mathrm{P}$ & & 0.25 & 0.14 \\
\hline $\mathrm{Mg}$ & $\mathrm{g} \mathrm{kg}^{-1}$ & 0.59 & 7.8 \\
\hline $\mathrm{S}$ & & 5.9 & 2.9 \\
\hline
\end{tabular}

(1) Results expressed in dry samples.

Source: Elaboration of the authors. 
Two soils were used, a clayey soil (Rhodic Kandiudalf) and a sandy soil (Arenic Hapludult) with clay contents of 577 and 150, sand 215 and 836 and, silt of 208 and $14 \mathrm{~g} \mathrm{~kg}^{-1}$ respectively. Soils were collected at depths between 0 and $20 \mathrm{~cm}$, sieved and distributed to pots with $4.5 \mathrm{~kg}$ of dry soil.
Calcium carbonate was applied in both soils to increase the $\mathrm{pH}$ to approximately 6 . Both soils were homogenates that were humidified $(50 \%$ of water retention capacity) and incubated for 30 days. Soils were sampled and analyzed after incubation (Table 3 ).

Table 3. Chemical analysis of clayey and sandy soils after incubation.

\begin{tabular}{|c|c|c|c|c|c|c|c|c|c|c|}
\hline Soils & $\begin{array}{l}\mathrm{pH} \\
(\mathrm{CaCl})\end{array}$ & $\begin{array}{l}\text { O.M. } \\
\mathrm{g} \mathrm{dm}^{-3}\end{array}$ & 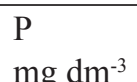 & K & $\mathrm{Ca}$ & $\mathrm{Mg}$ & $\begin{array}{c}\mathrm{H}+\mathrm{Al} \\
\mathrm{dm}^{-3}-\end{array}$ & SB & CEC & $\begin{array}{l}\mathrm{V} \\
\%\end{array}$ \\
\hline Sandy & 6.2 & 11 & 3 & 1.0 & 30 & 2 & 15 & 33 & 48 & 69 \\
\hline Clayey & 6.9 & 19 & 17 & 2.4 & 120 & 22 & 11 & 144 & 155 & 93 \\
\hline
\end{tabular}

Source: Elaboration of the authors.

Treatments consisted of urea coated in ashes in natura and zeolitized ash in rates of urea:ash (mass/ mass) with 100:10, 100:20, 100:50 and 100:100 along with a control of urea applied with no ash (100:0). The experimental design was randomized blocks with 4 replicates, including two of soils carried out separately.

Experimental units were arranged on the greenhouse floor to avoid interference on the capitation of volatilized ammonia by the air stream from exhausts. Experimental units were weighed weekly and irrigated to keep soil humidity to $50 \%$ of the capacity field.

Losses of ammonia were quantified through foam absorbers $\left(18 \times 18 \mathrm{~cm}\right.$, density of $\left.0.02 \mathrm{~g} \mathrm{~cm}^{-3}\right)$ treated with $90 \mathrm{~mL}$ of phosphoric acid solution $(0.25 \mathrm{M})$ containing $50 \mathrm{~mL} \mathrm{~L}^{-1}$ of glycerin. Treated absorbers were placed under PVC plates $(20 \times 20 \times 0.2 \mathrm{~cm})$ and covered by a polytetrafluorethylene (PTFE) that is permeable to ammonia and impermeable to water (ALVES et al., 2007).

Each experimental unit received an absorber foam plus PVC plate in order to avoid ammonia capitation from atmosphere. Absorber foam was placed to $1 \mathrm{~cm}$ of height supported by stems and it was replaced at 2, 4, 6, 9, 13 and 17 days after fertilizer application. The collected foams were stored in a freezer $\left(-4^{\circ} \mathrm{C}\right)$ until it was extracted and analyzed (ALVES et al., 2007).

Ammonia volatilized from soils was quantified by absolute control treatment with no $\mathrm{N}$ or ash and it carried out along with the experiment, under the same conditions, with four replicates for each soil. Data from absolute controls were used to quantify ammonia volatilized from the treatments.

The foam containing ammonia was individually washed with $300 \mathrm{~mL}$ of deionized water in a BuchnerKitassato vacuum funnel system. An aliquot of $50 \mathrm{~mL}$ of each wash from this disc was distilled and quantified by the method of Flow injection analysis (FIA) according to Su et al. (1998) and Kamogawa and Teixeira (2009).

Data of total N volatilized (TNV) were obtained from $\mathrm{N}$ volatilized from soil and fertilizer. $\mathrm{N}$ volatilized from fertilizer (NVf) was determined using the equation of NVf $=\mathrm{TNVt}-\mathrm{NVc}$. The letters $\mathrm{t}$ and $\mathrm{c}$ indicate the fertilizer treatment and absolute control, respectively.

After volatilization evaluations, soils were sampled in each experimental unit between 0 and $10 \mathrm{~cm}$ of depth using a probe to verify the chemical content of soils. 
Data obtained were analyzed by PROC GLM/ SAS (2004) through orthogonal contrasts comparing ashes with urea and ashes comparison among coverage rates.

Total ammonia volatilized showed no difference between the ashes used in urea coverage in both soils; however, urea coated with zeolitized ash had lower $\mathrm{N}$ loss when compared to control treatment in sandy soil $(p=0.02)$. Although zeolites contain distinct properties, they showed efficient results in the release of fertilizers, independently of the zeolites (ELLIOT; ZHANG, 2005).
Total ammonia volatilized, independent of the rates, for control treatment (urea), urea coated with ash in nature and urea coated with zeolitized ash were respectively $0.54,0.49$ and $0.37 \mathrm{~g}$ in clayey soil and $0.85,0.65$ and $0.54 \mathrm{~g}$ in sandy soil, representing respectively losses of 39,36 and $27 \%$ and 62, 47 and $39 \%$ from the total $\mathrm{N}$ applied.

Ashes evaluated in urea coverage only had an effect over total ammonia volatilized in sandy soil, independently of coverage rates (Table 4). The coverage rates in urea had similar ammonia losses in both evaluated ashes, with no statistical difference (Figure 1 and 2) for both soils (Table 4).

Figure 1. Total ammonia-N volatilized (\%) for rates of ashes added in urea in clayey soil. Averages followed by different letters are significant $5 \%$ by the Tukey test (CV 46\%).

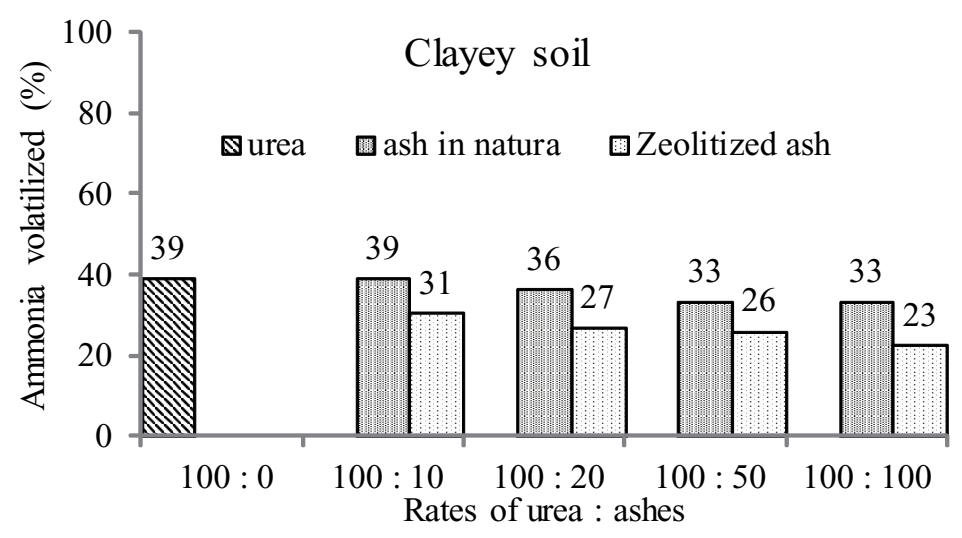

Source: Elaboration of the authors.

Figure 2. Total ammonia-N volatilized (\%) for rates of ashes added in urea in sandy soil. Averages followed by different letters are significant $5 \%$ by the Tukey test (CV 21\%).

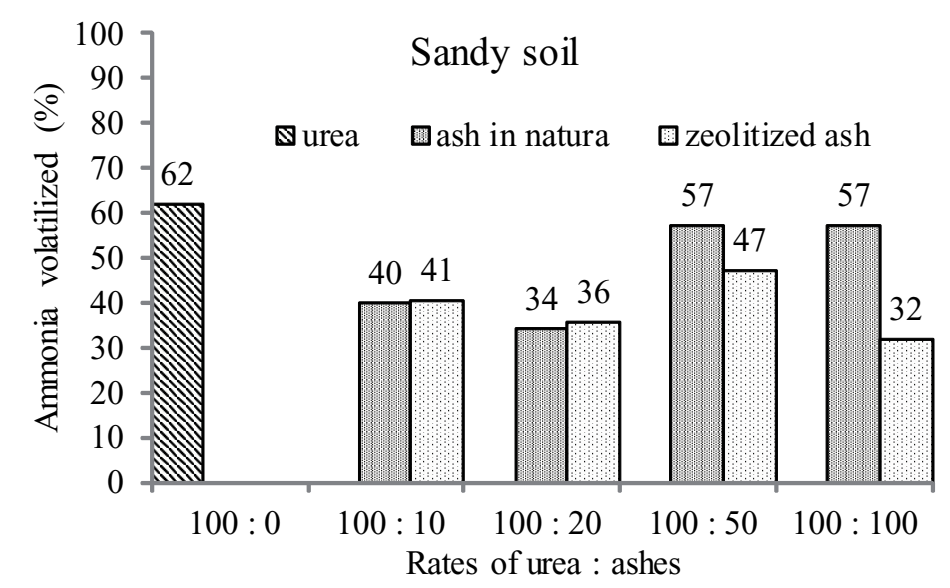

Source: Elaboration of the authors. 
The reduction of total ammonia volatilized showed a significant reduction as a consequence of the urea coverage rates applied in sandy soil; however, this effect was not observed in clayey soil (Table 4).

There is a different potential of volatilization for each soil. Clay and sand contents are the main components that affect ammonia volatilization. Clay may significantly reduce the ammonia volatilization as a consequence of its capacity to fix ammonium (FRANCISCO et al., 2011). Rates of urea:ash of 100:10 and 100:20 significantly reduced the total quantity of ammonia volatilized, independently of the ash, but only in sandy soil. With the rate of urea:ash of 100:50 there was a high quantity of ammonia volatilized allowing no establishment of a regression curve, similar to that observed by Alves et al. (2007) with levels of zeolite added to urea.

Table 4. Ammonia-N acummulated losses for rates of urea:ashes.

\begin{tabular}{|c|c|c|}
\hline \multirow{2}{*}{ Rates of urea: ashes ${ }^{1}$} & Clayey soil & Sandy soil \\
\hline & \multicolumn{2}{|c|}{ Ammonia-N volatilized (\%) } \\
\hline 100:0 & $39 \mathrm{a}$ & $62 \mathrm{~b}$ \\
\hline 100:10 & $35 \mathrm{a}$ & $40 \mathrm{a}$ \\
\hline $100: 20$ & $32 \mathrm{a}$ & $35 \mathrm{a}$ \\
\hline $100: 50$ & $30 \mathrm{a}$ & $52 \mathrm{ab}$ \\
\hline 100:100 & $28 \mathrm{a}$ & $45 \mathrm{ab}$ \\
\hline
\end{tabular}

${ }^{1}$ Rates of urea: ashes (mass/mass); Averages followed by different letters are significant $5 \%$ by the Tukey test.

Source: Elaboration of the authors.

The high quantities of ammonia loss in this study were similar to ammonia losses from urea applied to the surface in field as verified by Lara Cabezas, Korndorfer and Motta (1997). The high ammonia losses were a consequence of high $\mathrm{pH}$ and the initial soil humidity.

Curves of ammonia losses showed the largest volatilization reduction through ashes use, and this effect was verified statistically in sandy soil (Table 5). The largest ammonia losses were concentrated in the fourth day after fertilizer application (Figure 3 and 4), which was also verified by Alves (2006) and Lara Cabezas and Trivelin (1990). The volatilization peak occurred between the second and fourth day after urea application, but nitrogen losses may occur rapidly when urea is applied in humid soils with appropriate temperatures (CANTARELLA, 2007).

The effects of the ashes on the chemical characteristics of soil were identified by orthogonal contrast with a $5 \%$ level of significance (Table 6), possibly as consequence of the levels of soil acidity and different contents of clay and sand. 
Table 5. Orthogonal contrasts and significance of total ammonia-N volatilized (\%) in clayey and sandy soils.

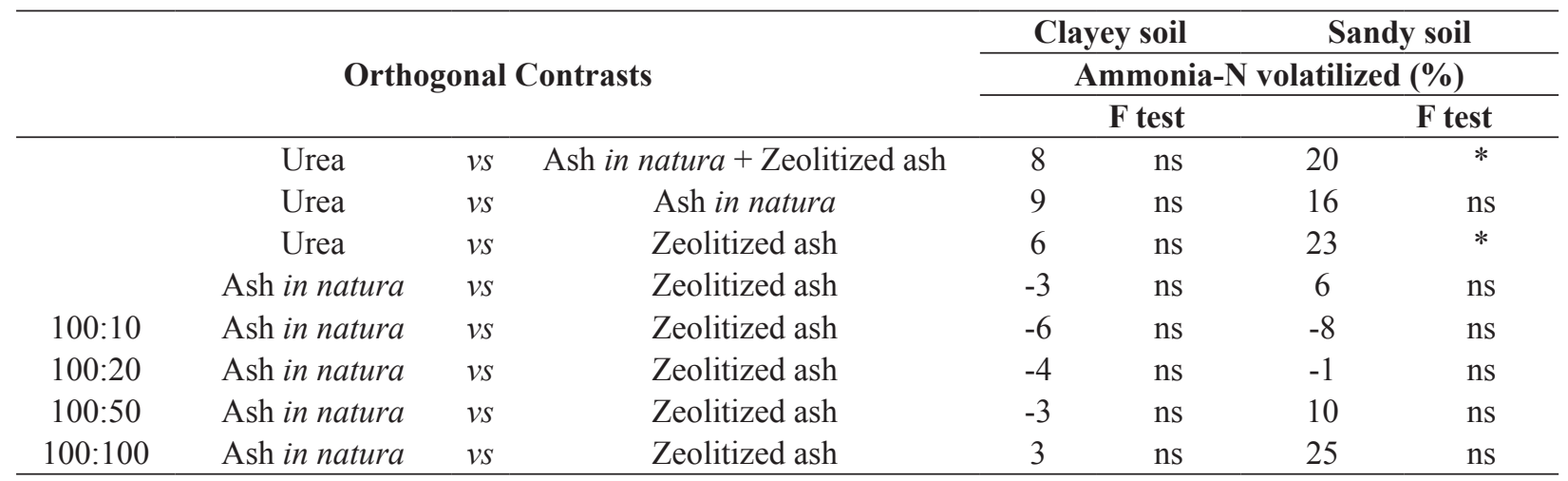

$*=$ significant to $5 \%$ by $\mathrm{F}$ test.

Source: Elaboration of the authors.

Figure 3. Ammonia-N losses from urea in 17 days after fertilizers application in clayey soil.

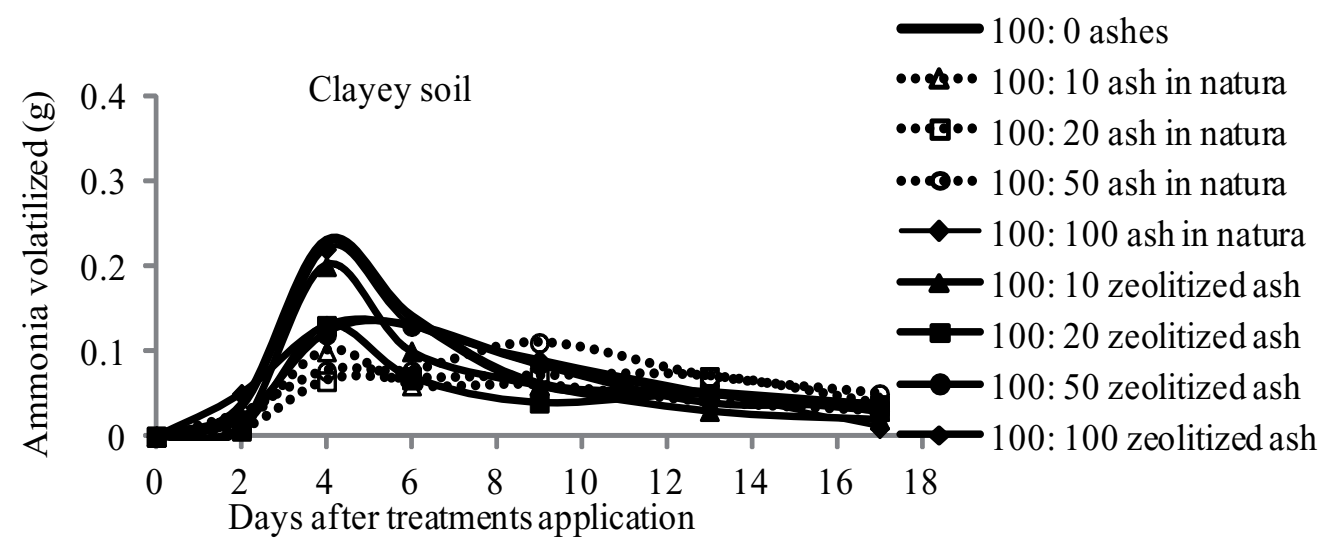

Source: Elaboration of the authors.

Figure 4. Ammonia-N losses from urea in 17 days after fertilizers application in sandy soils.

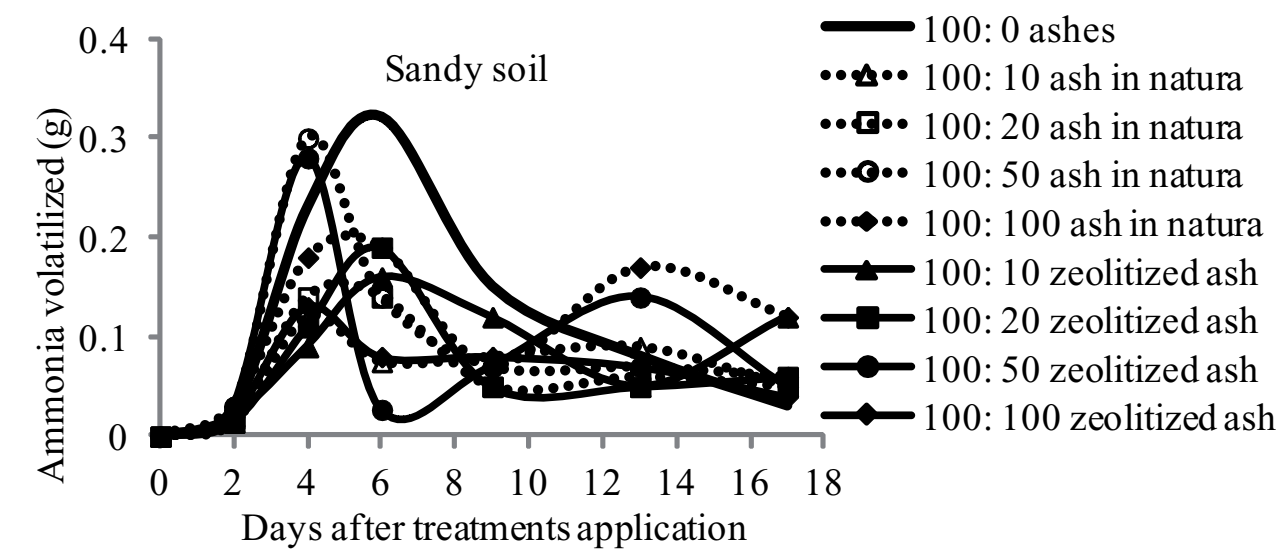

Source: Elaboration of the authors. 
Table 6. Chemical analysis of sandy soil for rates of urea:ashes 17 days after fertilizer application.

\begin{tabular}{|c|c|c|c|c|c|c|c|c|c|c|}
\hline Sandy soil & $\begin{array}{c}\mathrm{pH} \\
\mathrm{CaCl}_{2} \\
\end{array}$ & $\begin{array}{l}\text { O.M. } \\
\mathrm{g} \mathrm{dm}^{-3}\end{array}$ & $\begin{array}{c}\mathrm{P} \\
\mathrm{mg} \mathrm{dm^{-3 }} \\
\end{array}$ & \multicolumn{5}{|c|}{ 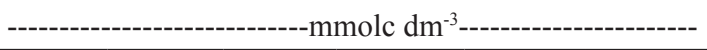 } & CTC & $\begin{array}{l}\mathrm{V} \\
\% \\
\end{array}$ \\
\hline Urea & 7.0 & 11.3 & 4 & 0.6 & 36 & 1 & 11 & 37 & 48 & 77 \\
\hline 100: $10^{1} \mathrm{Ash}$ in natura & 7.0 & 11.8 & 4 & 0.5 & 30 & 1 & 10.8 & 31 & 43 & 73 \\
\hline 100: 20 Ash in natura & 7.1 & 10.8 & 4 & 0.5 & 38 & 1 & 10.3 & 39 & 50 & 79 \\
\hline 100: 50 Ash in natura & 7.0 & 11.8 & 5 & 0.7 & 35 & 1 & 10.5 & 36 & 47 & 77 \\
\hline 100: 100 Ash in natura & 6.9 & 10.8 & 3 & 0.6 & 28 & 1 & 9.8 & 29 & 41 & 74 \\
\hline 100: 10 Zeolitized ash & 7.2 & 11.5 & 5 & 0.5 & 37 & 1 & 10 & 38 & 50 & 80 \\
\hline 100: 20 Zeolitized ash & 6.8 & 11.5 & 4 & 0.6 & 35 & 1 & 10.8 & 37 & 48 & 77 \\
\hline 100: 50 Zeolitized ash & 6.9 & 12.3 & 4 & 0.6 & 40 & 1 & 11.3 & 42 & 53 & 78 \\
\hline 100: 100 Zeolitized ash & 7.0 & 11.8 & 4 & 0.6 & 36 & 1 & 12 & 38 & 49 & 77 \\
\hline $\mathrm{CV}(\%)$ & 2 & 11 & 30 & 27 & 17 & 23 & 5 & 16 & 11 & 2 \\
\hline \multicolumn{11}{|l|}{ Clayey soil } \\
\hline Urea & 7.4 & 20.7 & 20 & 2.6 & 109 & 10 & 11 & 121 & 132 & 92 \\
\hline 100: 10 Ash in natura & 7.4 & 21.5 & 19 & 2.6 & 106 & 8 & 10.8 & 116 & 127 & 92 \\
\hline 100: 20 Ash in natura & 7.4 & 22.7 & 20 & 2.4 & 101 & 9 & 10.3 & 112 & 122 & 92 \\
\hline 100: 50 Ash in natura & 7.4 & 22.7 & 20 & 2.4 & 105 & 10 & 10.5 & 118 & 128 & 92 \\
\hline 100: $100 \mathrm{Ash}$ in natura & 7.5 & 23.0 & 20 & 2.4 & 108 & 9 & 9.8 & 119 & 129 & 93 \\
\hline 100: 10 Zeolitized ash & 7.4 & 21.2 & 19 & 2.4 & 96 & 9 & 10 & 107 & 117 & 92 \\
\hline 100: 20 Zeolitized ash & 7.5 & 22.0 & 19 & 2.2 & 96 & 9 & 10.8 & 106 & 117 & 91 \\
\hline 100: 50 Zeolitized ash & 7.5 & 21.2 & 19 & 2.2 & 119 & 10 & 11.3 & 131 & 142 & 92 \\
\hline 100: 100 Zeolitized ash & 7.4 & 21.3 & 18 & 2.4 & 101 & 9 & 12 & 112 & 124 & 90 \\
\hline $\mathrm{CV}(\%)$ & 1 & 8 & 7 & 7 & 13 & 13 & 5 & 12 & 11 & 1 \\
\hline
\end{tabular}

${ }^{1}$ Rates of urea: ashes (mass/mass)

Source: Elaboration of the authors.

In clay soil, urea coated with ash in natura had significantily reduced potential acidity $(\mathrm{H}+\mathrm{Al})$ when compared to the control treatments and urea coated with zeolitized ash. Potential acidity contents were 10,11 and $11 \mathrm{mmolc} \mathrm{dm}^{-3}$, respectively, for treatments with urea coated with ash in natura, control and urea coated with zeolitized ash.

Potassium content in clayey soil, analysed through orthogonal contrasts, were $0.2 \mathrm{mmolc} \mathrm{dm}^{-3}$ lower for treatments with urea coated with ashes than control, while the use of zeolitized ash resulted in levels $0.16 \mathrm{mmolc} \mathrm{dm}^{-3}$ lower than for ash use in natura.

The result of low potassium in soil with application of treatment urea coated with zeolitized ash is possibly related to cation exchange. Cation exchange is a reversible chemical reaction between a solution and cations from the solid phase (zeolite), thus its dynamic depends on zeolite selectivity (ELLIOT, ZHANG, 2005). The contents of calcium, CEC and Bases saturation (BS) in sandy soil were influenced by treatments through significant contrasts between the use of ashes in natura and zeolitized ashes for a rate of 100:100. Treatment of ash in natura showed contents of calcium, CEC and BS lower (4, 5 and 9 mmolc $\mathrm{dm}^{-3}$, respectively) than zeolitized ash. In the rate 100:100, the same contrast showed that ash in natura was lower $(9,8$ and 9 mmolc $\mathrm{dm}^{-3}$, respectively) for contents of calcium, $\mathrm{CEC}$ and $\mathrm{BS}$. 
The use of urea coated with ashes in rates of (urea:ash) 100:10 and 100:20 contributed to a significant reduction of ammonia volatilization in sandy soil.

There was no difference between ashes in natura or zeolitized ashes for reduction of nitrogen losses by ammonia volatilization, i.e., there is no need to process ash to this goal if it is used in adjusted rates.

Fertility parameters have a low influence from ashes added to urea, thereby the effects depend on soils and ash treatment.

\section{References}

ALVES, A. C. Métodos para quantificar a volatilização de $\mathrm{N}-\mathrm{NH}_{3}$ em solo fertilizado com ureia. 2006. Dissertação (Mestrado em Zootecnia) - Faculdade de Zootecnia e Engenharia de Alimentos. Universidade de São Paulo, Pirassununga.

AlveS, A. C.; AlveS, T. C.; MACEDO, F. B.; BERNARDI, A. C. C.; OLIVEIRA, P. P. A.; ROCHETTI, R. C. Adição de zeólita para redução da volatilização de amônia em solo fertilizado com ureia. São Carlos: Embrapa Pecuária Sudeste, 2007. 4 p. (Embrapa Pecuária Sudeste. Circular Técnica 55).

BARTZ, J. K.; JONES, R. L. Availability of nitrogen to sudangrass from ammonium saturated clinoptilolite. Soil Science Society of American Journal, Madison v. 47, p. 259-262, 1983.

BERNARDI, A. C. C.; MONTE, M. B. M.; PAIVA, P. R. P.; WERNECK, C. G.; HAIM, P. G.; POLIDORO, J. C. Potencial de uso de zeólita na agropecuária. São Carlos: Embrapa Pecuária Sudeste, 2008.

CANTARELLA, H. Nitrogen. In: NOVAIS, R. F.; ALVAREZ V., H.; BARROS, N. F.; FONTES, R. F. F.; CANTARUTTI, R. B.; NEVES, J. C. L. (Ed.). Fertilidade do solo. Viçosa, MG: Sociedade Brasileira de Ciência do Solo, 2007. p. 375-470,

CANTARELLA, H.; MATTOS JUNIOR, D. de; QUAGGIO, J. A.; RIGOLIN, A. T. Fruit yield of valencia sweet orange fertilized with different $\mathrm{N}$ sources and the loss of applied N. Nutrient Cycling in Agroecosystems, Dordrecht, v. 67, n. 3, p. 215-223, 2003.

ELLIOT, A. D.; ZHANG, D. Controlled release zeolite fertilizers: a value added product produced from fly ash. World of Coal Ash (WOCA), Lexingtoy, Kentucky, USA, p. 11-15, apr., 2005.
FERGUSON, G.; PEPPER, I. Ammonium retention in soils amended with clinoptilolite. Soil Science Society of American Journal, Madison, v. 51, n. 1, p. 231-234, 1987.

FRANCISCO, S. S.; URRITIA, O.; MARTIN, V.; PERISTEROPOULOS, A.; GARCIA-MINA, J. M. Efficiency of urease and nitrification inhibitors in reducing ammonia volatilization from diverse nitrogen fertilizers applied to different soil types and wheat straw mulching. Journal of the Science of Food and Agriculture, Oxford, v. 91, n. 9, p. 1569-75, 2011.

KAMOGAWA, M. Y.; TEIXEIRA, M. A. Autoamostrador de baixo custo para análise por injeção em fluxo. Química Nova, São Paulo, v. 32, n. 6, p. 1644 -1646, 2009.

LARA CABEZAS, W. A. R.; KORNDORFER, G. H.; MOTTA, S. A. Volatilização de N-NH3 na cultura de milho: i. efeito da irrigação e substituição parcial da ureia por sulfato de amônio. Revista Brasileira Ciência do Solo, Viçosa, v. 21, n. 3, p. 481-487, 1997.

LARA CABEZAS, W. A. R.; TRIVELIN, P. C. O. Eficiência de um coletor semi-aberto estático na quantificação de N-NH3 volatilizado da ureia aplicada ao solo. Revista Brasileira de Ciência do Solo, Campinas, v. 14, n. 3, p. 345-352, 1990.

OLIVEIRA, P. P. A. Manejo da calagem e da fertilização nitrogenada na recuperação de pastagens degradadas de Brachiaria sp. em solos arenosos. 2001. Tese (Doutorado em Ciências) - Centro de Energia Nuclear na Agricultura, Piracicaba.

OSTE, L. A.; LEXMOND, T. M.; VAN RIEMSDIJK, W. $\mathrm{H}$. Metal immobilization in soils using synthetic zeolites. Journal of Environmental Quality, Madison, v. 31, n. 3, p. 813-821, 2002.

SAS Institute Inc. SAS OnlineDoc ${ }^{\circledR}$ 9.1.3. Cary, NC: SAS Institute Inc. 2004.

SOARES, J. R. Redução de perdas por volatilização de $\mathrm{NH}_{3}$ pela adição de compostos à ureia. 2008. Monografia (Engenharia Agronômica) - Escola Superior de Agricultura Luiz de Queiroz, Piracicaba.

SU, X. L.; CHEN, P.; QU, X. G.; WEI, W. Z.; YAO, S. Z. A novel flow-injection system for simultaneous determination of nitrate and nitrite based on the use of a zinc reductor and a bulk acoustic wave impedance detector. Microchemical Journal, Changsra, v. 59, n. 3, p. 341-350, 1998.

TRENKEL, M. E. Slow and controlled-release and stabilized fertilizers: an option for enhancing nutrient use efficiency in agriculture. Paris: Paris International Fertilizer Industry Association, 2010. 167 p. 
VITTI, A. C.; TRIVELIN, P. C. O.; GAVA, G. J. C.; PENATTI, C. P.; BOLOGNA, I. R.; FARONI, C. E.; FRANCO, H. C. J. Produtividade da cana-de-açúcar relacionada ao nitrogênio residual da adubação e do sistema radicular. Pesquisa Agropecuária Brasileira, Brasília, v. 42, n. 2, p. 249-256, 2007. 